The volume ends with illustrated reproductions of colophons from Pona's debated works, and an extended bibliography.

SEBASTIANO BAZZICHETTO

University of Toronto

\title{
Bucer, Martin.
}

De vera et falsa caenae dominicae administratione (1546). Ed. Nicholas Thompson.

Studies in Medieval and Reformation Traditions 184. Leiden: Brill, 2014. Pp. xiv, 320. ISBN 978-9-0042-7323-8 (hardcover) €126/\$163.

This is a book for Bucer scholars; a high level of familiarity with his works and doctrine is assumed and necessary. Having said that, Thompson's introductory material does add sharper definition to the context in which De vera et falsa was written-and this is interesting, even if the treatise itself adds little to our understanding of Bucer's theology as a whole. Bucer was known as a compromiser; he advanced formulae aimed at reconciling first Luther and Zwingli and subsequently Protestants and Catholics, and was therefore somewhat distrusted by all sides and often pilloried for his efforts. Nonetheless he wrote treaties and letters to all interested parties, clear in the belief that neither side in any dispute could be allowed an absolute victory. De vera et falsa, little regarded at the time, falls into this diplomatic-theologic effort.

Thompson also provides a pithy biography of Bartholomaeus Latomus who was Bucer's main opponent at the Regensberg assemblies and a target of the treatise. Like Bucer, Latomus disliked the obscurantism of the scholastics and the hide-bound doctrinaire traditionalists alike; he was no evangelical, however, aligning instead with the Catholic reformers of the Pole or Contarini camp. If Bucer could have swayed Latomus to support more clear-cut reform, other moderates (he believed) may have followed suit-but sola scriptura and the council of Trent became obstacles to any agreement. Latomus was far more willing to subscribe to channels of traditional reform and authority-the pope, the emperor and the general council-so he took a wait-and-see stance, whereas Bucer hoped and held out for a comprehensive Germany-based council with equal evangelical participation. At the centre of their dispute were three 
contentious issues - the Mass (communion in one kind, Eucharist, sacrifice), invocation of saints, and clerical celibacy - which Trent brought to a wider audience. De vera et falsa was published as a counterpoint to Trent and as a clarification of Bucer's position. The bulk of the book is Thompson's critical edition, and Bucer scholars should appreciate the result.

The letter-preface is a short address to the representatives at Trent rehearsing the usual evangelical rallying points against "works righteousness" added to pleas for sola scriptura, vernacular translations, and sola fide. Bucer wanted a comprehensive re-examination of both liturgy and practice to eliminate human precepts and reform the church's clear material orientation. This is followed up with a very brief address to Latomus (featuring an account of their long running polemic dispute) highlighting past disagreements over "communion in one kind" and other abuses in the Mass (although book 1's forty-five sections do not ignore other important issues). Authority, church or gospel, was at the heart of the Bucer/Latomus dispute. Latomus argued that as written the gospel liturgy does not apply to all laity (only to the apostles and their clerical descendants) so the cup should not be given, while Bucer offered a compromise with the argument that as other rites and ceremonies have changed over time and due to circumstance (e.g., baptism) there must be room for discussion on this point too (as outlined in the forty sections of book 2). Bucer brought into the discussion his work with another moderate Catholic, John Gropper (on whom the introduction could have usefully provided another brief biography). The heart of the discussion and proposed compromise is the question of the Mass as a sacrifice. Bucer took the position that the elements of the Eucharist do represent a kind of sacrifice, referring to the ancient practice of communal offerings of wine and bread which were subsequently employed in the communal celebratory feast. Similarly, the Catholic practice of intercessionary prayers for the dead could be legitimized as an obscured version of the ancient practice of joyful recollection of the recently dead, while purgatory built too much around Augustinian speculations and too-literal readings of ancient texts. There was room for manoeuvre: for Bucer, the Lutherans were moving in the right direction with the removal of human precepts and innovations (which he called on Trent to follow), but he allowed that there was no genuine bar to evangelicals attending Catholic Masses. He reasoned that the invisible church of true believers was within the body of professed believers and that the Mass, whatever its contemporary faults, did at least resemble the true ancient rite. By such argument 
Bucer wanted only to show that the Mass and its associated prayers and liturgy had been subverted from their true meaning and that recapturing the truth did not require much more effort than the admission from the representatives at Trent that humans make mistakes. Circumstances were against him and his treatise, however, sandwiched as it was between the assembling of Trent, the Schmalkaldic War (1546-47) and the Augsburg Interim. Thompson noted that De vera et falsa became for Bucer a "final notice of the stark choice facing every Christian" (39) as he went into exile.

There can be no argument that the modernization and translation of primary sources is an important and useful endeavour and that Thompson has done some admirable and careful work here, correcting previous typographical errors spread by uncritical (and now online) editions of the treatise. Importantly he has also eased the language of the treatise into a more readable format (expanding abbreviations, supplying alternate readings of ambiguous passages, deconstructing obscure passages, and modernizing spelling and punctuation), but a passing familiarity with Latin is still necessary to get the full impact of the text. I wonder why an English translation was not produced and included in the same volume-a minor complaint with regard to an otherwise excellent piece of scholarship.

ANDREW A. CHIBI

Sheffield, UK

\section{Buck, Lawrence P.}

The Roman Monster: An Icon of the Papal Antichrist in Reformation Polemics. Early Modern Studies 13. Kirksville, MO: Truman State University Press, 2014. Pp. xiii, $258+13$ ill. ISBN 98-1-612481-06-7 (paperback) \$49.95.

In early 1496 in Rome, reports began to circulate about a strange hybrid monstrosity found among the detritus left by the Tiber as it receded following the previous month's flooding. According to the earliest accounts, this creature had the body and head of an ass, but with the breasts and pudendum of a woman. Its appendages, too, were a worryingly unnatural mix of forms: one hand human, the other the tip of an elephant's trunk; one foot a claw, the other a cloven hoof. On its backside was the face of a bearded old man, and a tail-at the tip 